\title{
6
}

\section{Sir Roland Wilson - Primus Inter Pares}

\author{
Selwyn Cornish
}

When Roland Wilson was inducted into the military cadets at age 14 he weighed scarcely $25 \mathrm{~kg}$; at full height he was only $158 \mathrm{~cm} .^{2} \mathrm{He}$ was clearly a person of slight build and short stature. But he frequently reminded those who drew attention to these facts that his endowment of brainpower was more than adequate compensation. He could run intellectual rings around ministers, business leaders, academics, public servants and journalists. Yet he was not only highly intelligent; he also possessed moral courage and had a biting wit. According to Douglas Copland, Wilson at an early age exhibited 'force of character and capacity for leadership'. ${ }^{3}$ As to wit, a colleague remarked that Wilson used it 'for many a devastating one liner', adding that the 'one-liner could be humorous, or it could be like a whiplash' ${ }^{4}$

Wilson stood up to some of the most powerful men in this country and abroad, including Eddie Ward and John Foster Dulles. Tom Fitzgerald, the finance editor of the Sydney Morning Herald, accurately summed up Wilson when he said that '[b]y his intelligence and force of character, Sir Roland Wilson has been the outstanding public servant of his generation'. ${ }^{5}$ John Maynard Keynes, who observed Wilson in action at a conference in London during the war, reported that he and other Whitehall officials had 'the greatest respect for his wisdom and for his pertinacity'. ${ }^{6}$

\footnotetext{
1 This paper draws heavily on the following three publications: S. Cornish, Sir Roland Wilson: A Biographical Essay (Canberra: The Sir Roland Wilson Foundation, 2002); W. Coleman, S. Cornish and A. Hagger, Giblin's Platoon: The Trials and Triumphs of the Economist in Australian Public Life (Canberra: ANU E Press, 2006); and S. Cornish, 'Roland Wilson', in J.E. King, Biographical Dictionary of Australian and New Zealand Economists (Cheltenham: Edward Elgar, 2007). These publications relied strongly on Roland Wilson's personal papers, which at the time were privately held and not catalogued. The National Library of Australia (MS 1155) now holds the papers, and a descriptive list is available. Unless otherwise indicated, quotes are drawn from these papers.

2 A. Reid, 'The Czar of the Treasury', Bulletin (Sydney), 21 December 1960, 10. See also J. Hetherington, 'Roland Wilson: A Matter of Money', in Hetherington, Uncommon Men (Melbourne: F.W. Cheshire, 1965), 187. 3 D. Copland, 'Confidential Statement' to Rhodes Scholarship Selection Committee, 28 October 1924, University of Tasmania archives, Tasmanian Archive and Heritage Office, file 34/5/50.

4 R.J. Whitelaw, Farewell Address to his Treasury Colleagues, 7 November 1986, held by author.

5 T. Fitzgerald, quoted in John Farquharson, 'Outstanding Public Servant of his Generation', Canberra Times, 27 October 1996.

6 J.M. Keynes to L.F. Giblin, 13 November 1942, Reserve Bank of Australia Archives, RBAA C. 3.7.6.33.
} 
Sir Paul Hasluck, a minister throughout the entire period of Wilson's tenure as secretary to the Treasury, wrote that Wilson

gained in authority among inexpert ministers firstly because he gave an impression of having no political motive of his own but a scientific detachment when describing the economic outlook and the problems to be faced and secondly because he never "squared off" to ministers, or flattered, or cajoled them, or tried to ingratiate himself with them. He was polite but uncompromising and ... left the feeling that he was treating them as though they could understand the ... issues, even when he was exposing the flaws in some remark a minister had made. ${ }^{7}$

For John Stone, a later Treasury secretary, the predominant reason for the Treasury's power and prestige during the 1950s and 1960s was the fact that, with Wilson at its head, it 'had a brilliant economist and outstanding public servant'; 'one felt that as the head of one's department, one was extraordinarily fortunate to have a highly distinguished man', for he was

seen and regarded in and around Canberra, as being not merely ... an intellectual giant to some degree, but also in the Public Service, a bureaucratic giant ... That simply derived from his personality and his force of mind and indeed, his force of expression also. He was an extraordinary lucid thinker and writer, and on occasion, speaker. ${ }^{8}$

According to Stone, 'Wilson's contribution to the Treasury ... was that he gave it a sense of being led by an outstanding figure - someone, so to speak, that the department could look up to. He gave it intellectual quality. ${ }^{\prime 9}$

\section{Education}

Wilson was born at Ulverstone, Tasmania, on 7 April 1904 and died in Canberra on 25 October 1996, aged 92. He was the first of his immediate family to complete secondary school and attend university. His formal education began at the convent school in Ulverstone, the same school that the state premier and later prime minister Joseph Lyons had attended many years before. ${ }^{10}$ Upon completion of primary school he won a junior bursary, which allowed him to proceed to the public high school in Devonport. There he topped the state junior examination

7 P. Hasluck, The Chance of Politics (Melbourne: Text Publishing, 1997), 55.

8 J. Stone, interviewed by B. Schedvin, 17 May 1991, National Library of Australia (NLA).

9 J. Stone, Eulogy: Sir Roland Wilson, St John the Baptist Anglican Church, Reid, ACT, 1 November 1996, Papers of Sir Roland Wilson, NLA MS 1155.

10 The Wilsons were Protestants. Wilson's mother thought that by attending the convent school her son would associate with a rather more refined group of fellow pupils than he would were he to attend the local state primary school. 
and was placed second in the senior (matriculation) examination. Again, he secured a state scholarship, which enabled him to enrol for the commerce degree at the University of Tasmania. He studied economics under two of Australia's leading economists, D.B. Copland and J.B. Brigden. He had not planned to go to university, and his father was reluctant to allow him to do so. It was only after Copland came to Ulverstone to meet his father that he was allowed provisionally to attend the university for one year, which was extended for a second and then a third and fourth year when success followed success. ${ }^{11}$

Wilson was awarded the 1925 Rhodes Scholarship for Tasmania, the first Tasmanian Rhodes scholar to come from a state school, and the first to be selected from the Faculty of Commerce. He possessed neither Greek nor Latin. For these reasons his selection was attacked in an unsigned letter to the Mercury, Tasmania's leading newspaper. He was so badly stung by the criticism that he considered rejecting the scholarship. But he changed his mind after receiving a stern lecture on the meaning of moral courage by a member of the Rhodes selection committee, the substance of which he was never to forget.

In his referee's report to the Rhodes committee, Copland wrote that Wilson

is certainly the most brilliant student that has passed through my hands since I came to Tasmania. His record of High Distinctions is evidence of this, but it does not convey at all an adequate impression of his remarkable mental powers.

... His analytical powers are marked, and will eventually give him a high place among economists if he continues with the subject. He has shown balanced judgements and some degree of original thought which will doubtless become more evident as his studies progress. I am convinced that he will possess to quite an unusual degree the ability to do higher work in economics and that his election to a Rhodes Scholarship will ultimately bring distinction to the country. ${ }^{12}$

When Wilson reached Oxford he discovered that the university did not recognise the commerce degree from the University of Tasmania and he was compelled to take the Diploma in Economics and Political Science (which he completed with distinction) before being permitted to enrol for postgraduate studies. In his first year at Oxford he wrote an essay on the subject of 'Social and Economic Experiments in Queensland from 1860' for the Beit Prize in Colonial History, one of the university's most prestigious prizes. The essay was successful; one of the judges considered it to be 'the best Beit Essay that has been submitted for some years'. Having won the Beit Prize, Wilson was then permitted to enrol for the

11 University of Tasmania archives, Tasmanian Archive and Heritage Office, file 34/5/50.

12 University of Tasmania archives, Tasmanian Archive and Heritage Office, file 34/5/50. 
degree of Doctor of Philosophy (D.Phil). He undertook research on the subject of 'The Import of Capital' and devoted a considerable amount of time to collecting statistical data for his thesis. His examiners agreed that he had 'handled an intricate subject with great ability', and that his work was 'worthy of publication'. ${ }^{13}$

Before finishing his degree at Oxford, Wilson was elected to a Commonwealth Field Scholarship (later known as the Harkness Scholarship) to undertake postgraduate studies at the University of Chicago. There he decided to enrol for another doctorate. He chose the topic of 'Capital Movements and their Economic Consequences', which allowed him to pursue some of the themes that he had foreshadowed in his work at Oxford. His supervisor was the redoubtable Jacob Viner, who held Wilson to be 'one of the two or three best students I have ever encountered'. He predicted that Wilson would 'have a highly successful career as a teacher and scholar'. According to Viner, Wilson was 'an exceptionally able student and researcher, quick, original, industrious and systematic. He writes freely and well, and expresses himself easily and effectively. He has an unusual degree of intellectual maturity for a person of his age. ${ }^{\prime 4}$

\section{Contributions to economic research}

After completing his degree at Chicago, Wilson was offered a lectureship at the University of Tasmania and returned to Hobart. He commenced publishing articles based on the research he had conducted for his doctorates. In 1931, Melbourne University Press published a book based on his Oxford and Chicago work entitled Capital Imports and the Terms of Trade. Sir Roy Harrod, the eminent Oxford economist, reviewed the book in the Economic Journal. He wrote that it was 'a notable contribution to the statistical study of international payments', and 'a valuable addition to the literature of international trade'. ${ }^{15}$

Of Wilson's contributions to economics, perhaps the most arresting was his examination in Capital Imports of the effect of capital inflows on the terms of trade of the borrowing country. Received accounts asserted that the terms of trade - that is, the ratio of export prices to import prices - of the borrowing country would improve. In contrast, Wilson found for Australia that the terms of trade tended to be correlated inversely with inflows of capital. His main interest, however, was not with the external terms of trade, but rather with the internal terms of trade: what would happen to the price ratio of 'domestic' (or non-tradeable goods) to tradeable goods (exports and import-replacement goods)

13 D.H. Macgregor, Reference for Roland Wilson, 3 December 1931, NAA 1606, AJ25/1.

14 J. Viner, Reference for Roland Wilson, 5 January 1932, Wilson Papers, NLA MS1155.

15 R.F. Harrod, Review of Capital Imports and the Terms of Trade, by R. Wilson, Economic Journal, 42, no. 167 (1932). 
in the case of a capital importing country? On the basis of hypothetical models, supported by empirical data, he concluded that, in Australia's case, 'domestic' (or non-tradeable) prices tended to rise relatively to prices for tradeable goods. Whereas movements in the prices of internationally traded goods tend to be constrained by international competition, there were usually no such constraints on the costs and prices for many 'domestic' goods and services. ${ }^{16}$

Professor Trevor Swan argued in his review in 1972 of Treasury Paper No. 1, entitled Overseas Investment in Australia, that it should have been called Treasury Paper No. 2, since the Treasury's explanation of the adjustment process, by which the balance of payments accommodated overseas borrowing, was the same as the one that had been elucidated by Wilson in his book published in 1931. ${ }^{17}$ Swan himself had drawn on Wilson's explanation in his own work on internal-external balance. Indeed, H.W. Arndt referred 'to the quite significant Australian contributions - by Roland Wilson and Trevor Swan - to the development of the "small country case" in the theory of balance of payments adjustment'. ${ }^{18}$ It has also been claimed that Wilson's work was the precursor of what has since been termed the 'Dutch disease' or 'the Gregory effect'.

\section{Public servant}

Wilson was not entirely comfortable working as an academic economist. He later admitted that he 'never felt deeply attracted to scholarship for its own sake'. ${ }^{19}$ Instead of an academic career, Wilson thought he might prefer to work as a policy adviser to governments. An opportunity arose in 1932 when L.F. Giblin, the acting Commonwealth statistician, invited him to take the position of economist in the Statistician's Branch of the Commonwealth Treasury in Canberra. The offer was accepted and he was quickly promoted to assistant Commonwealth statistician. He was the first economist to be employed at a senior level in the Commonwealth Public Service. His appointment - which was to be for six months - was not accepted with equanimity. Several members of the Public Service Union who worked in the Statistician's Branch called a strike, and Eddie Ward criticised the appointment in the parliament. Later, however, when Ward was minister for Labour and National Service, and Wilson was the head of his department, Ward declared that Wilson was 'the most able man I have met' $^{\prime 20}$

16 R. Wilson, Capital Imports and the Terms of Trade (Melbourne: Melbourne University Press, 1931).

17 T.W. Swan, 'Overseas Investment in Australia', Treasury Economic Paper No. 1, Economic Record, March 1976, 7 .

18 H.W. Arndt, 'Non-Traded Goods and the Balance of Payments', Economic Record, March 1976, 89.

19 Address at the Commemoration Ceremony, University of Tasmania, Hobart, April 1969.

20 I. Castles, 'Menzies' Economic Commander', Australian, 30 October 1996, 14; Elwyn Spratt, Eddie Ward: Firebrand of East Sydney (Adelaide: Rigby, 1965; reprinted by Seal Books, Adelaide, 1978), 70. 
In 1935, after declining the chair of economics at Tasmania and the associated post of financial adviser to the Tasmanian Government, Wilson was appointed economic adviser to the Commonwealth Treasury. Giblin had urged him to stay in Canberra rather than moving back to Hobart, informing Wilson that his work for the Commonwealth was 'the bigger job'. Then, in 1936, at the age of 32, Wilson succeeded E.T. McPhee as Commonwealth statistician, a post he was to hold until he was appointed secretary to the Commonwealth Treasury in 1951.

When he was Commonwealth statistician in the 1930s, Wilson created the position of 'Research Officer', which allowed graduates to enter the Commonwealth Public Service on the basis of their university qualifications. Until then, graduates could only enter the service as base grade clerks, unless they held professional qualifications, such as medical doctors or engineers; Wilson himself had been an exception. Among the distinguished graduates he recruited to the Bureau were Arthur Smithies, John Burton, Jim Nimmo, Dick Heywood, Mick Shann and Lindsay Brand. On a number of occasions he tried to attract J.G. Crawford, but without success.

Shortly before the outbreak of war, Wilson was appointed, together with Giblin and L.G. Melville of the Commonwealth Bank, to the Advisory Committee on Financial and Economic Policy (the F and E Committee). Wilson had himself proposed the establishment of this committee and had nominated Giblin to chair it. It was to be responsible for planning and coordinating much of the financial direction of the war in its early stages, and for investigating possible approaches to post-war reconstruction. In addition, as part of Australia's defence planning, Wilson was placed in charge of the National Register of the male population. This work included a census of wealth for which Wilson was responsible.

In 1940, Wilson was asked by the government to establish the Department of Labour and National Service and to become its inaugural head. He quickly created a division of post-war reconstruction in the department. It was here that the early planning of Australia's post-war reconstruction was undertaken, and to which Wilson recruited an impressive group of economists and other university graduates, including Arthur Tange, Allen Brown, Gerald Firth, Fin Crisp and John Burton. Earlier, Wilson had been responsible for bringing H.C. Coombs into the Treasury from the Commonwealth Bank in Sydney. It was this group, including Coombs, that was to form the nucleus of the Ministry of Post-War Reconstruction when it was formed at the end of 1942.

Because Wilson had initiated work on post-war reconstruction in the Department of Labour and National Service, he was invited to represent Australia at the first British Commonwealth conference on the international economy in the post-war era held in London in October 1942. It was at this conference that Keynes outlined his proposal for an international monetary institution aimed 
at securing international financial stability; the idea was to evolve into the International Monetary Fund established at Bretton Woods in 1944. Keynes informed Giblin that, at the London conference, Wilson had taken a "prominent, indeed a leading part through all the discussions and played a major role in them with the greatest success' ${ }^{21}$

Wilson did not attend the Bretton Woods conference, but he was at the conference in San Francisco in 1945 that established the United Nations Organization. Here again he distinguished himself. It was largely because of Wilson's skill and tenacity that the Australian Government's objective of full employment was successfully incorporated into the Charter of the United Nations (clauses 55 and 56), the outcome of a battle that Wilson won against powerful American opposition led by John Foster Dulles. Paul Hasluck, who also attended the San Francisco conference, wrote that, of the large Australian delegation led by ministers Forde and Evatt, 'Wilson was quietly the master' ${ }^{22}$

\section{Secretary to the Treasury}

Late in 1948 a selection committee for the inaugural chair of economics at the newly established Australian National University (ANU), comprising the vice-chancellor (Douglas Copland), W.K. Hancock (professor of economic history at Oxford and one of the four advisers to the Interim Council of ANU), J.R. Hicks (professor of economics at Oxford and a later Nobel Laureate) and Sir Henry Clay (warden of Nuffield College, Oxford), decided to offer the chair to Wilson. But he declined the offer, explaining to Copland that, although he had made some contributions to economic knowledge, he doubted that he had the capacity for sustained research in economics of the kind that would be expected of a professor in a research school. 'I do not believe', he wrote to Hancock, 'that I possess in sufficient measure the scholarly instincts and attributes without which one could neither tolerate nor be tolerated in a research school in the social sciences.' Copland, however, tried to reassure Wilson that 'it should be quite possible for you to take charge of a research department in economics even though you have, as you say, been immersed in policy administration for so many years'. But Wilson was adamant, informing Copland that he had 'reluctantly but firmly declined the invitation'. In addition to having 'a sense of inadequacy on the academic side', Wilson confessed to Copland that he

was also to some extent influenced by my disinclination to break the long association I had with the Commonwealth Service. I feel strongly

\footnotetext{
21 J.M. Keynes to L.F. Giblin, 13 November 1942, Reserve Bank of Australia Archives, RBAA C. 3.7.6.33.

22 P. Hasluck, Diplomatic Witness: Australian Foreign Affairs, 1941-1947 (Carlton, VIC: Melbourne University Press, 1980), 193.
} 
that I have been too long out of the academic world to make a satisfactory research Professor of Economics, and if I accepted such a position I should always feel that I was holding it under false pretensions. You will have seen enough of Government service yourself to know that one is forced to become rather specialized in certain requirements, and that this specialization does not contribute much to the breadth and profundity of knowledge required in one who is to fill an important academic post. You must not conclude that I am suffering from an inferiority complex, which is far from true. I am merely trying to be honest about my present situation, and to suggest that the National University would be wise to seek someone of less questionable suitability for the position which has so many potentialities for the future of economics in Australia. ${ }^{23}$

Following his rejection of The Australian National University's offer of the chair in economics, Wilson was appointed secretary to the Treasury on 1 April 1951. At 47 years of age, he was the youngest person to hold the position until Bernie Fraser's appointment in 1984. The duration of Wilson's tenure as Treasury secretary - some 15 years - has not been surpassed. Nor have others exceeded his reputation. As secretary he was the nation's senior economic policy adviser; indeed, he was the nation's most senior public servant. These were extraordinary years, marked by full employment, relative price stability and sustained economic growth. It is sometimes suggested that Wilson's reputation is overestimated because of the favourable circumstances that existed during these halcyon days. It is true that Wilson was not confronted with the problems that beset his predecessors during the depression of the 1930s or the two world wars. Nor did he have to confront the upsurge of inflation that began shortly after he left the Treasury. Nevertheless, in an era when public expectations of a benign economy were widely prevalent, the impact of each cyclical fluctuation tended to be magnified in the minds of many Australians. And since the downturns were often policy-induced, as part of the management of aggregate demand aimed at dampening inflationary forces and preserving balance of payments stability, the Treasury, as the responsible department, was frequently the target of public disquiet, and its head was often the subject of personal criticism.

The 'credit squeeze' of 1960-61 was arguably the most difficult event that Wilson had to contend with during his time as Treasury secretary. The recession of the early 1960s was the steepest in 30 years, until it was exceeded by the recession of the early 1980s. Both Wilson and the Treasury came in for heavy criticism. He never denied his responsibilities as secretary to the Treasury. Nor did he panic. Cool as always under pressure, he set about to restore economic stability and the Treasury's reputation. Both objectives were quickly achieved. His close colleagues

23 S. Cornish, 'The Appointment of the ANU's First Professor of Economics', History of Economics Review, no. 46 (2007). See also Australian National University Archives, ANUA 104/1/8 Pt 3. 
wrote to him after the economy began to rebound from the immediate effects of the recession to congratulate him on his judgement and courage. Stanley Carver, the Commonwealth statistician, wrote to him at the end of 1962, saying that the

outcome has vindicated your clear vision. I truly believe that you averted a boom-collapse of a kind that could have made the burst bubbles of Sydney Guarantee, Hooker and Reid Murray [companies that had recently collapsed] look like incidents ... It is a perilous and painful thing to destroy false doctrine - and even harder to revive an economy rotten with little South Sea Bubbles. Yet I think you have succeeded and prevented collapse. ${ }^{24}$

Similarly, his Treasury colleague, Lenox Hewitt, wrote to him in January 1963 asking

whether you've now looked back, in leisure, over your achievements in 1962? They should give you great satisfaction ... You've built a fine organization in a year of quite extraordinary achievement. How extraordinary, I feel I am one of those able to judge. ${ }^{25}$

Wilson chose to leave the Treasury three years ahead of the compulsory retiring age of 65. The decision reflected in part his wish to allow his deputy, Sir Richard Randall - another of the seven dwarfs - the opportunity to head the Treasury. ${ }^{26}$ But there were also other reasons. Menzies had just retired and was succeeded as prime minister by Harold Holt who, in turn, was replaced as treasurer by William McMahon. With these ministerial changes, Wilson thought it was time for a change at the top of the Treasury. Moreover, the chairmanship of the boards of Qantas Airways and the Commonwealth Banking Corporation were about to fall due and Wilson was ready to take on new challenges.

When he retired from the Treasury in 1966 he had already spent many years on the boards of the Commonwealth Bank and Qantas as secretary to the Treasury. Upon retirement he was appointed chairman of both these enterprises. In due course he was appointed to the chairmanship of the Wentworth Hotel, a fully owned subsidiary of Qantas, and to the boards of the insurance company Mutual Life \& Citizens (MLC), Imperial Chemical Industries (Australia), and the Australian-European Finance Corporation. As with everything else he did, Wilson took his work as a company director seriously and his contributions to strategic thinking were highly praised both by his fellow directors and by managers in the companies with which he was associated.

\footnotetext{
24 S. Carver to R. Wilson, 21 December 1962, Wilson Papers, NLA MS 1155.

25 L. Hewitt to R. Wilson, 14 January 1963, Wilson Papers, NLA MS 1155.

26 S. Cornish, 'Sir Richard John Randall (1906-1982)', Australian Dictionary of Biography, 18 (Carlton, VIC: Melbourne University Press, 2012), 324-5.
} 


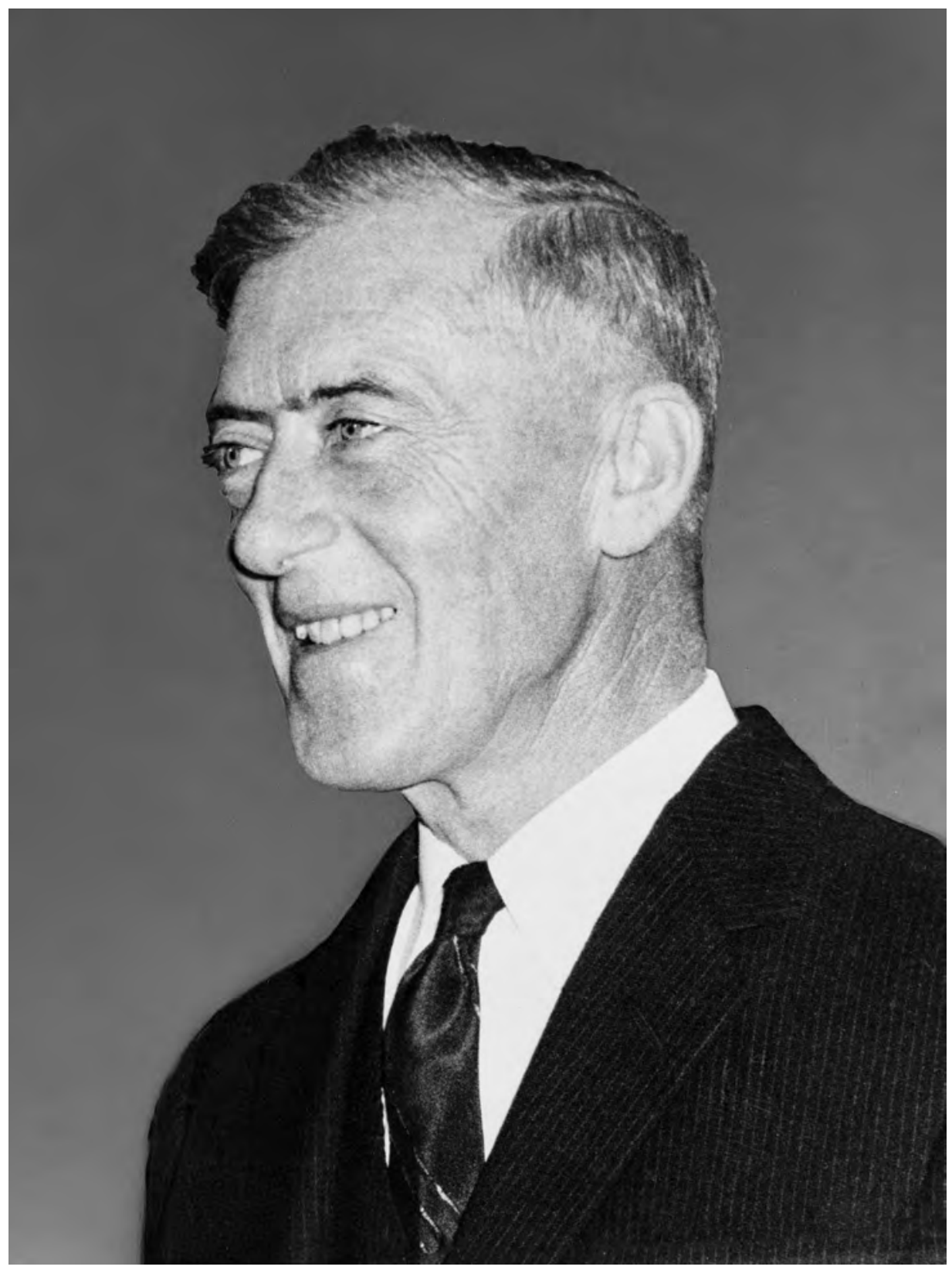

\section{Sir Roland Wilson, 1965}

Source: National Archives of Australia, A1200, L51130 


\section{Wilson's legacy}

What is the significance of Wilson's life and work? An obvious one is that high intellectual ability and steadfast determination can transcend limited family circumstances and the obscurity of the place of one's birth. Born the son of a builder and cabinet maker, in an isolated country town in the smallest and least economically equipped of the Australian states, a young man with limited physical presence but with considerable academic ability and a courageous disposition was able to aspire, and later to be offered and attain, positions at the apex of his nation's academic, bureaucratic and corporate worlds. He was fortunate, to be sure, in having as mentors some of the leading names in Australian economics and politics, among them Giblin, Copland and Brigden, Lyons, Casey, Menzies, Spender, Holt, Fadden, Curtin and Chifley. But he had to win their support, which he did as a result of his powerful intellect and strength of character.

Of his principal achievements, the most significant was surely the part he played in the transformation of the Treasury from its traditional accounting and budgetary function to an institution whose chief responsibility was the provision of economic advice to government. Wilson did not initiate this transformation. Nor was the transformation complete by the time he left the Treasury. But as economic adviser to the Treasury in the 1930s and 1940s, and as secretary to the Treasury in the 1950s and 1960s, there can be no doubt that he, more than any other individual, played the dominant role in the evolution of the Treasury from a department of finance and supply to a department of economic policy advice. When he was appointed Treasury secretary, the Launceston Examiner - the leading newspaper in the region of his birth - drew attention to the fact that an economist had succeeded an accountant as head of the department. It pointed out that '[f]or fifty years Treasury administration has been in the hands of persons who were predominantly accountants and graduates from the Treasury's accounting departments'. But Wilson's appointment was altogether different, for it 'marks the first Australian experiment of this kind, and it is a good bet as far ahead as one can see all his successors will be economists, too' ${ }^{27}$

Wilson's direction of the Treasury was heavily influenced by ideas that he had developed in the 1930s. It was then that he had taken an interest in aspects of policy coordination and planning. He wrote two important papers on the subject, one on 'The Economic Implications of Planning', for the Australian Institute of Political Science in 1934, and the other on 'Economic Co-ordination', the Joseph Fisher Lecture, which he presented at the University of Adelaide in 1940. ${ }^{28}$

\footnotetext{
27 Launceston Examiner, 2 February 1952, 2.

28 R. Wilson, 'The Economic Implications of Planning', in W.G.K. Duncan, ed., National Economic Planning (Sydney: Angus and Robertson, 1934); R. Wilson, 'Economic Co-ordination', Joseph Fisher Lecture in Commerce (Adelaide: The Hassell Press, 1940).
} 
Given the need and inclination of modern governments to intervene in the economy, Wilson was concerned about the scope for policy conflict and the inconsistencies of objectives and decisions that were likely to occur in these circumstances. It was clear to him that planning was required to coordinate the various interventions, and to bring about a greater measure of coherence in economic policy. Planning, he argued,

may be regarded as the elaboration of methods for securing wise control. Practically, it involves the establishment of some form of central 'thinking agency', which will be better equipped than the existing political organization, to direct where direction is necessary, and to withhold where intrusion would be harmful.

By planning he did not mean the type of planning that had materialised in the Soviet Union. What he had in mind, though of course he could not spell it out, was something like the Treasury of the 1950s and 1960s when Wilson himself was the secretary - a 'thinking agency' that would operate in a market economy and would aim to achieve greater consistency between competing policy objectives. As he put it,

the new planning demands a reversal of short-sighted economic policies, the abolition of arbitrary and ill-conceived restraints and interferences with the free workings of the automatic adjustments, and, above all, a more vigorous and rational control of the machinery for creating and distributing purchasing power.

The years of Wilson's headship of the Treasury are often regarded as the high watermark of the Keynesian revolution in Australia, and it is sometimes contended that Keynesianism was the guiding principle of the department's approach to economic policy. While it might be argued that Wilson was never a committed adherent to Keynesianism, he was in some ways a purer adherent to the economics of Keynes than many of those who claimed to be dedicated Keynesians. Neither Wilson nor Keynes were supporters of direct controls. Keynes often referred to them as 'Bolshevism', or 'totalitarian' devices, and Wilson no doubt would have agreed. Like Keynes, he was not attracted to the idea of constantly fine-tuning the economy, particularly by manipulating interest rates, doubting as he did the potency of monetary policy. Both men preferred instead to influence activity by fiscal policy. While agreeing that monetary policy had a role to play, where they differed was in their time horizons - Wilson backed the Menzies Government's strong commitment to economic expansion, whereas Keynes was more concerned with achieving short-term stability.

Accordingly, some of Wilson's greatest work was directed at fostering a more efficient and dynamic economy. He was opposed to Australia's high rate of 
protection, often clashing with the Department of Trade under its minister, John McEwen, and secretary, J.G. Crawford. While endorsing the reimposition of import controls in the emergency circumstances that prevailed in 1952, when a flood of imports inundated Australia following the bursting of the Korean War boom, Wilson opposed quantitative import controls in principle as a permanent feature of the Australian economy, preferring instead a more adjustable exchange rate regime. He was a powerful advocate of the return to convertibility of sterling area currencies, arguing that Australia's adherence to sterling area controls was imposing a straitjacket on the nation's efforts to force the pace of economic growth and development. As well as his support for convertibility, Wilson was an architect of policy aimed at overcoming the dollar shortage of the 1950s by borrowing in the United States, policy advice that the Menzies Government received favourably but which had been anathema to the previous Chifley administration. On wages policy, Wilson believed that the system of arbitration and conciliation, with its support for quarterly adjustments to the basic wage according to movements in retail prices, was contributing both to inflation and to inefficiencies in the allocation of resources.

There continued to be major differences over policy between the Treasury and the Commonwealth Bank/Reserve Bank during Wilson's time as Treasury secretary, particularly between Wilson and Coombs, the heads of the two agencies. These difficulties might have had their origins during the war and over aspects of post-war reconstruction. They were probably heightened when Coombs, shortly after his appointment to the governorship of the Commonwealth Bank at the end of 1948, wrote to Wilson saying:

I have always felt it essential that there should be another source of economic advice and some authority concerned with the coordination of inter-departmental work other than the Treasury. It seems to me inevitable that the Treasury, however good its intentions and however able its staff, gradually comes to take the traditional 'financial' point of view and there are many times when this point of view is not the most relevant. ${ }^{29}$

As an alternative source of policy advice, Coombs proposed that the prime minister should have attached to him an economic staff. Wilson was to retain a copy of this letter with his personal papers for the rest of his life.

Similarly, Coombs' decision to invite the nation's top academic economists to the Commonwealth Bank/Reserve Bank twice a year for consultations on the state of the Australian economy was regarded with deep suspicion by Wilson, especially when an invitation to participate was extended to Crawford and other officials of 
the Department of Trade. Alarm bells rang even louder when Wilson discovered attempts in the early 1950s by Coombs to fund from the Commonwealth Bank work at The Australian National University on contemporary economic trends and issues, the results of which were to be published on a regular basis. Such an exercise, Wilson thought, might cause the government acute embarrassment and inevitably weaken the Treasury's authority as the principal economic adviser to the federal government. ${ }^{30}$

The problem of an alternative source of economic advice to government reached its apogee in 1965 when the Committee of Economic Enquiry (the Vernon Committee) recommended that an Advisory Council on Economic Growth should be established to advise the government on economic matters. The Vernon Committee had been established in 1962 in the wake of the credit squeeze of 1960-61. Crawford had been designated by the prime minister to chair the enquiry; when Wilson heard about it he persuaded Menzies to replace Crawford with a businessman, Dr James Vernon, much to Crawford's chagrin. ${ }^{31}$ By the time its report was completed the economy had recovered and the econometric forecasts that had underpinned the committee's analysis of the future seemed incongruent with the new economic dispensation. Wilson and his Treasury colleagues exploited the factual deficiencies and logical inconsistencies of the Vernon Report to impugn its major recommendations, including, above all, the arguments supporting the creation of an Advisory Council on Economic Growth. In this endeavour, Wilson was highly successful. For when he tabled the Vernon Committee's report in the parliament, Prime Minister Menzies, drawing upon a Treasury brief, announced that the government did not accept the need for an alternative source of economic advice. For Wilson, there were no grounds for creating new sources of policy advice, since the Treasury itself evaluated different possibilities. Furthermore, the Treasury was not the only public agency advising the government: 'The problem', he argued, was 'not how to get advice but how to evaluate it. To set up competitive evaluations still leaves the task of evaluating the evaluators.' ${ }^{32}$ That, Wilson thought, was clearly the role of the Treasury.

Wilson's - and the Treasury's - difficulties with Coombs, and with Crawford, have sometimes been explained simply in terms of powerful egos refusing to yield

30 Wilson's contempt for the Bank had already formed before Coombs became governor. In January 1949 he wrote to Coombs about his return to Australia from the United States and the resumption of his seat on the Bank's Advisory Council. Wilson told Coombs that '[t]hese [duties], of course, include at least one lunch per meeting, sherry twice a day, afternoon tea once a day, and the frequent use of the Governor's plane for the transport of myself, my Treasury colleagues and my secretary between Canberra and Sydney. In between other activities no doubt we will find time at the Council to consider some items of business, if there are any on which you have not made up your mind before the Council meets.'

31 Crawford was subsequently appointed vice-chairman, becoming in effect the principal author of the Enquiry's report.

32 Wilson Papers, NLA MS 1155. 
to different points of view. There is something to be said for this explanation. After all, Wilson, Coombs and Crawford were the most senior of the seven dwarfs. But there was more to it than that, for there were significant differences in their approaches to economic policy. The Treasury's priority under Wilson and Randall was to facilitate and enhance economic growth and development. Policies that might inhibit this objective were clearly unacceptable to the Treasury. The central bank, when Coombs was governor, was more concerned with short-term stability, being always ahead of the Treasury in wanting to tighten policy for the purpose of reducing inflation. Coombs was generally eager to use monetary instruments for this purpose, but Wilson was concerned that higher interest rates would increase the cost of servicing government debt, much of the debt having accumulated as a result of funding infrastructure projects. Moreover, fine-tuning aggregate demand tended to induce stop-go cycles in activity, which adversely affected decision-making in the private sector of the economy. The Department of Trade, for its part, wanted to provide tariff and other protection - and subsidies - to local industries, both export and import-replacing industries. For Wilson, however, this meant the diversion of resources into less efficient sectors of the economy, a process that would impede Australia's growth and development.

The Treasury's Economic Survey, which was published annually from 1956 to 1973, reveals the department's overriding commitment to economic growth and development. In his Foreword to the first Economic Survey in 1956, the prime minister (Menzies) put the Treasury's view precisely:

By reducing the pressure of home demand the Government has sought to reduce the demand for imports, to reduce the external deficit, and at the same time to assist in stabilizing domestic costs and prices. Initially, the only measures which could be used forthwith to safeguard international solvency were negative rather than positive. They included import restrictions, and restraint of domestic expenditures through higher taxes and ceilings on public works. The Government, however, has always been fully alive to the need for a positive strengthening of the bases of our domestic economy to provide for continued economic growth. This calls for greater productivity and output, especially in those lines of activity where our competitive position is strong and through which we can hope to improve our balance of payments position; it calls likewise for selective basic investment which will contribute to this, and for the domestic saving and overseas borrowing necessary to support it. ${ }^{33}$

33 Commonwealth of Australia, Australia 1956: An Economic Survey (Canberra: Commonwealth Government Printer, 1956), 5. 
In the same Economic Survey, the Treasury itself argued that, rather than the achievement of full employment, the 'outstanding feature of the post-war Australian economy has been its many-sided and remarkable continuous growth ... It has had force enough to thrust aside obstacles and keep going in face of events which, in other times, would have staggered the economy.' While some aspects of this expansion were due to government policy - such as immigration and basic infrastructure - the Treasury asserted that economic expansion

has been a spontaneous movement, drawing its impetus from many sources within the economy ... there has been nothing in the nature of a general plan, drawn up and imposed by the authority of government. Throughout the community there has no doubt been something of a general conviction that the economy ought to grow, had to grow, and should not be hindered from growing and various elements in the economy, including governments, have acted in accordance with that conviction. But apart from that kind of general belief, it would be difficult to say that the movement has had any single source of inspiration, energy or sponsorship. It has nevertheless operated most powerfully to shape the course of events. ${ }^{34}$

The Treasury's enthusiasm for economic growth was expressed dramatically in its 1963 Economic Survey: 'Over the past ten years', the Treasury wrote,

and especially over the past three years, Australia has achieved its greatest break-through in point of resources since the crossing of the Blue Mountains a hundred years ago. That earlier event opened the first doorway to the pastoral and agricultural wealth of the continent and the growth since built upon it. But until not very long ago it was commonly held that Australia could not be a great industrial nation and therefore could not support any greater number of people at Western standards because it lacked industrial resources. The quick succession of rich mineral discoveries - bauxite, copper, iron ore and now oil - go far to dispel that view - these new riches do, beyond doubt, lift the horizons of Australian growth quite incalculably. ${ }^{35}$

In its next Survey, the one for 1964, the Treasury identified a problem that was to beset the Australian economy in the years to come. There were 'two divergent possibilities', it said. 'One is that growth will continue ... The other possibility is a renewal of inflation and the beginning of a phase of unstable

34 Ibid., 13-14.

35 Commonwealth of Australia, The Australian Economy (Canberra: Commonwealth Government Printer, 1963), 24-5. 
conditions extending far into later years. Clearly there is in this a challenge both to government and to the whole community.' ${ }^{36}$ No one could say that Wilson and Randall did not warn Australia of the possible dangers ahead.

\section{Conclusion}

In his Giblin Memorial Lecture to the 47th ANZAAS Conference held in Hobart in 1976, Wilson chose to reflect upon the qualities and outlook required of successful economic policy advisers. Though he was speaking of Giblin, his thoughts applied equally to himself:

[H]e [Giblin] would have felt that, in the application of economic theory to public policy, the need was greater rather than less for the cultivation of people who could combine a basic mastery of theory with knowledge of the mysteries of a constantly changing society, with intimate experience of business and political realities, with intuitive understanding of the behaviour of individuals, and groups within society - and above all with humanity.

... He made a unique mark in government, in economics, in central banking, in statistics and in war ... from his vast knowledge and experience was distilled a wisdom which was put without stint at the disposal of those who knew and loved him. ${ }^{37}$

36 Commonwealth of Australia, The Australian Economy (Canberra: Commonwealth Government Printer, 1964), 3.

37 R. Wilson, 'L F Giblin: A Man for All Seasons', address to the 47th Congress of the Australian and New Zealand Association for the Advancement of Science, Hobart, 12 May 1976; published in Search (Sydney, NSW), 7, no. 7 (July 1976), 314. 
This text is taken from The Seven Dwarfs and the Age of the Mandarins: Australian Government Administration in the Post-War Reconstruction Era, edited by Samuel Furphy, published 2015 by ANU Press, The Australian National University, Canberra, Australia. 